\title{
Analysis of opportunities for biofuel production in sub-Saharan Africa
}

\author{
Graham von Maltitz, Lorren Haywood, Maxwell Mapako and Alan Brent \\ Natural Resources and the Environment, Council for Scientific and Industrial Research (CSIR), Pretoria, South Africa
}

\section{Introduction}

The world's population consumes more oil than any other single energy source, including coal, natural gas, nuclear, hydro and renewables (EIA 2005). By 2030, global demand for oil is expected to have increased by 50 per cent (IEA 2008:116). Rising prices, concerns about energy security and acceptance of global warming impacts have sparked worldwide efforts to replace oil rapidly with alternative energy sources (IEA 2008:55). In particular, biofuels - a renewable hydrocarbon energy source derived from biomass - have much potential as a sustained alternative energy supply of liquid fuels (IEA 2008:307). Within the developing world, and especially Africa, biofuels, are also regarded as a potential mechanism to stimulate agricultural development, create jobs and save foreign exchange (von Maltitz and Brent 2008). In reaction to the initial euphoria about biofuels as a carbon-neutral alternative to fossil fuels, numerous popular articles and scientific papers have cautioned against the global drive towards a biofuels economy, highlighting the potential impacts on food security, poor energy efficiencies and potential environmental harm (Gallagher 2008; IEA 2008: 332; Royal Society 2008).

\section{What are biofuels?}

Bioethanol and biodiesel are the most commonly produced biofuels, and currently these are derived mainly from food crops such as maize, soya and sugarcane. Biofuels derived from food crops are known as first-generation biofuels. Bioethanol is produced by

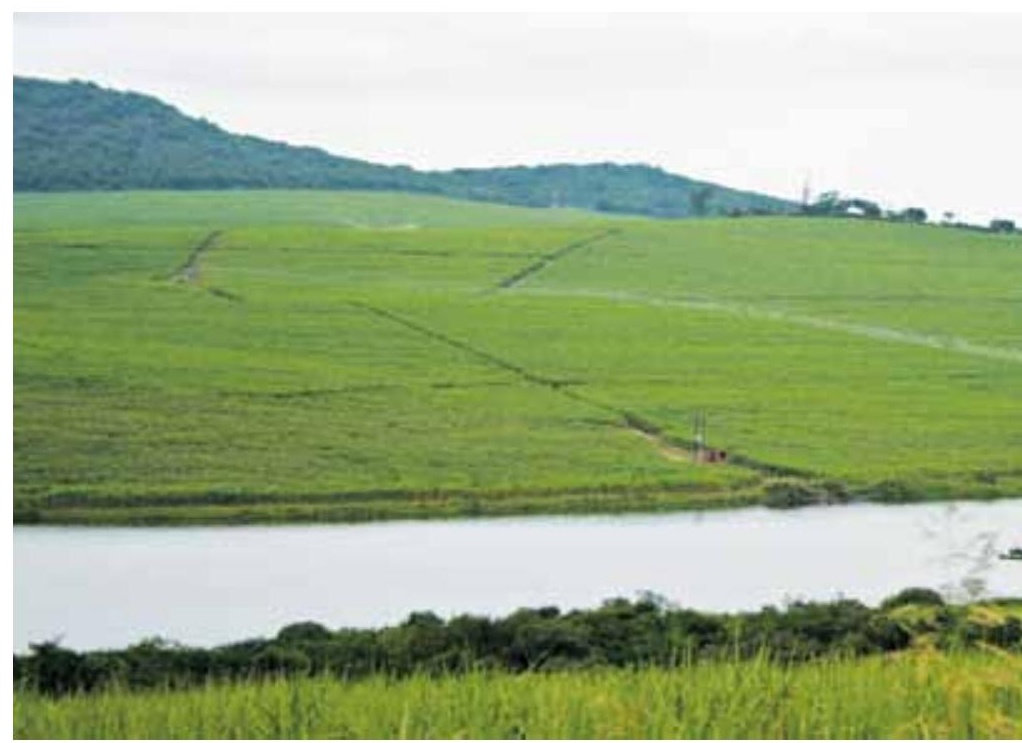

South Africa produces almost twice the sugar the country consumes, predominantly from large-scale plantations such as these on the Kwazulu Natal coast (Photo by Gareth Borman)

fermenting sugars and starch, and can be blended with petroleum up to approximately 10 per cent in normal, petrol-driven engines, or used in any blend to 100 per cent in modified engines. Biodiesel is produced through a process of transesterification from oils or fats, and can be used in almost any diesel engine or mixed with conventional petroleum diesel. Pure vegetable oil can also be used in specially modified diesel engines.

New technologies in advanced stages of development will allow alternative feedstocks to be used for 


\section{Fuel use in sub-Saharan Africa}

As a continent, Africa has the lowest per capita energy consumption. Biomass in the form of charcoal and fuelwood continues to be the main fuel source for most sub-Saharan countries (see Table 1). Low consumption levels reflect low economic development, and also hinder economic development. Biofuels are a relatively new concept and although bioethanol was used as a petroleum supplement in the past in countries including Malawi, South Africa and Zimbabwe, it is only in the last few years that large-scale biofuel production has been seriously considered.

\section{Biofuel expansion drivers in Africa}

The European Union has proposed mandatory biofuel blends with petroleum of five per cent by 2015, and 10 per cent by 2020 (to be reviewed in 2014), as a mechanism to reduce carbon emissions. Since the EU is unable to meet its biofuel target due to insufficient agricultural land available in Europe, this has created an international market for biofuels. European and other investors are placing strong pressure on African countries to make more land available for biofuel feedstock to meet European biofuel and global carbon reduction targets. Africa's interest in this market is driven predominantly by the need for economic growth, especially among rural communities. Biofuel production represents an opportunity to boost rural economies by supplying international markets for fuel crop products and, in turn, opening markets for agricultural surpluses. The concern is that the economic benefits of biofuels to African countries may be minimal, especially if raw feedstock is exported for processing elsewhere (von Maltitz and Brent 2008; Haywood et al. 2008).

Of the 40 countries within sub-Saharan Africa, 14 are landlocked. Further, nearly 40 per cent of Africa's population lives in landlocked countries where transport costs on average are 50 per cent higher than in coastal countries. Biofuel production offers African countries importing petroleum a means to achieve energy security and the possibility of reducing the foreign currency demands for importing oil.

\section{Types of biofuel projects in sub-Saharan Africa}

It is impossible to obtain an accurate figure for the status of biofuel projects across Africa. The situation is very dynamic with new investments being announced monthly, often to simply disappear. A large number of projects are in the planning phase, but few are fully operational. Hagan (2007), for instance, suggests that current projects in 10 West African countries represent an investment of US\$126 million, with plans to install processing capacity for 70 million litres of biodiesel and 165 million litres of bioethanol per year. But, as far as can be ascertained, none of these projects are operational. On an Africa-wide scale, the proposed biofuel expansion equates to tens of millions of hectares.

African biofuel projects can be divided into four basic types based on the scale of production and intended use of the biofuels (see Figure 2).

Table 1. Annual energy consumption characteristics of sub-Saharan Africa and selected countries compared to global trends

\begin{tabular}{lcccc}
\hline & $\begin{array}{c}\text { Energy use per } \\
\text { capita (kgoe) }\end{array}$ & $\begin{array}{c}\text { Total energy from } \\
\text { biomass and waste in \% }\end{array}$ & $\begin{array}{c}\text { Electricity } \\
\text { consumption per } \\
\text { capita (kWh) }\end{array}$ & $\begin{array}{c}\text { Liquid fuel } \\
\text { consumption } \\
\text { per capita* }\end{array}$ \\
\hline World & 1796 & 9.7 & 2678 & 751 \\
Sub-Saharan Africa & 681 & 56.3 & 542 & 117 \\
Ghana & 397 & 66.0 & 266 & 122 \\
Tanzania & 530 & 92.1 & 61 & 45 \\
Kenya & 484 & 74.6 & 138 & 101 \\
Mozambique & 497 & 85.4 & 450 & 39 \\
\hline
\end{tabular}

Source: Compiled from World Bank 2008

*Calculated from 2004 oil consumption and population data at www.eia.doe.gov/emeu/international 


\section{Scale of the project}

\begin{tabular}{|c|c|}
\hline $\begin{array}{l}\text { Small-scale growers on 1-99 ha and } \\
\text { outgrowers }\end{array}$ & $\begin{array}{l}\text { Large industrial farms of } \\
100 \text { ha or more }\end{array}$ \\
\hline $\begin{array}{l}\text { Type 1* } \\
\text { - Mali Folkecentre } \\
\text { - Dumpong Biofuels in Ghana }\end{array}$ & $\begin{array}{l}\text { Type } 2 \\
\text { - Commercial farmers in South Africa } \\
\text { and Zambia } \\
\text { - Mines in Zambia }\end{array}$ \\
\hline $\begin{array}{l}\text { Type } 3 \\
\text { - Outgrowers linked to commercial } \\
\text { plantations } \\
\text { - Small-scale farmers linked to commercial } \\
\text { biofuels fuel-processing plants }\end{array}$ & \begin{tabular}{l}
\multicolumn{1}{c}{ Type 4} \\
Large-scale commercial plantations in \\
Tanzania, Mozambique and Madagascar \\
growing for EU markets
\end{tabular} \\
\hline
\end{tabular}

Figure 2. Typical biofuel projects grouped by scale of farming activity and intended use of the biofuel product

* Type 1 projects are described in boxes $A$ and $B$

In Type 1 and 2 projects, biofuels are produced to meet local needs. These projects are typically small and have been initiated in several African countries including Mali, Ghana, Mozambique, Tanzania and Zambia (see Box A). These projects are often initiated by nongovernmental organisations (NGOs) and supported by national governments or international donors.

\section{Box A. Biodiesel success in Ghana}

The negative impact of rising fuel prices on rural communities prompted a team from the United States to set up a biodiesel production unit known as Dumpong Biofuels in a small village in Ghana. The project aimed to work alongside the Dumpong Pineapple Growers Cooperative to produce biodiesel for transport, farm equipment operation and electricity generation. On 2 July 2007, the team started building a biodiesel processor from locally accessible materials in a village near Aburi in Ghana. The processor was assembled in only two days and started to produce biodiesel immediately; 550 litres of biodiesel was produced in the first three days. The feedstock is palm kernel oil sourced from neighbouring villages. The palm nuts are crushed and boiled to extract the oil. No further refining is undertaken before the oil is processed to make biodiesel, which is 75 per cent cheaper than the local petroleum diesel that has to be imported. Some of the fuel was used to power a small bottling plant, since clean drinking water was scarce (http:// dumpongbiofuels.org/).
Although mostly based on small growers who provide the feedstock (Type 1), some largescale farmers and mining companies are also planting biofuel crops to meet their own fuel requirements (Type 2 ; see Box $B$ ). Biofuels are commonly part of a mixed cropping system for both small and large-scale farmers.

In contrast, Type 3 and 4 projects are dedicated biofuel production enterprises established specifically to meet the demands for national and international fuel blends. As such,

\section{Box B. Mali case study: Integrated energy platforms}

Biofuels for sustainable energy generation at village level are being piloted in various locations in Africa, with the Mali Folkecenter project in Garalo, Mali, probably the most advanced. Three 100 KVA marine gensets have been installed that are capable of running on pure jatropha oil. The jatropha will be grown by local farmers, and financed by selling the electricity. The idea is that in the long term, the village will have sustainable, locally produced electricity. While the jatropha fields mature, diesel is being used to supplement the energy generation. Many NGOs that are critical of large-scale biofuels are strongly supportive of this local model for energy and economic development (www. malifolkecenter.org). 


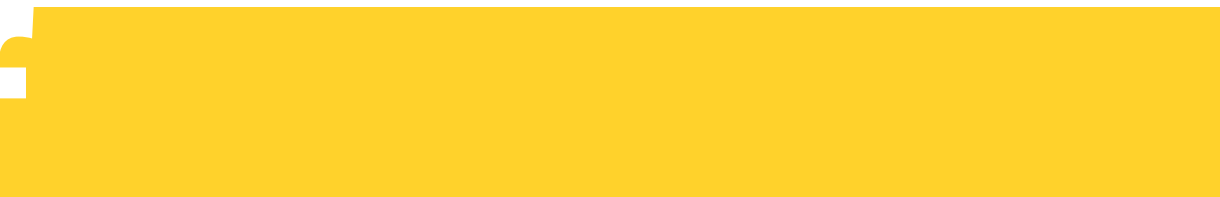

farmer's landholding is converted to feedstock production. The biofuel industry provides support and inputs, financing, technological assistance and a market. Arguably, biofuels are an attractive farming option on account of the assistance received by the farmers, rather than the intrinsic value of the biofuel crop itself (Haywood et al. 2008).

Since Type 1 and 2 projects are aimed at only meeting local fuel needs, they are not considered to have major negative social or environmental impacts; indeed, their proponents see potential positive impacts. If these projects prove to be non-viable, the repercussions will be minimal. By contrast, the magnitude of Type 3 and 4 projects could result in extensive land transformation and consequential biodiversity loss. In addition, unless well managed, there is a high risk of unintended negative social consequences, such as food insecurity and communities displaced from their land. In Type 3 and 4 projects, there are also concerns that industrial plantations provide either a large number of poorly paid job opportunities if not mechanised, or better-paid but fewer opportunities if mechanised.

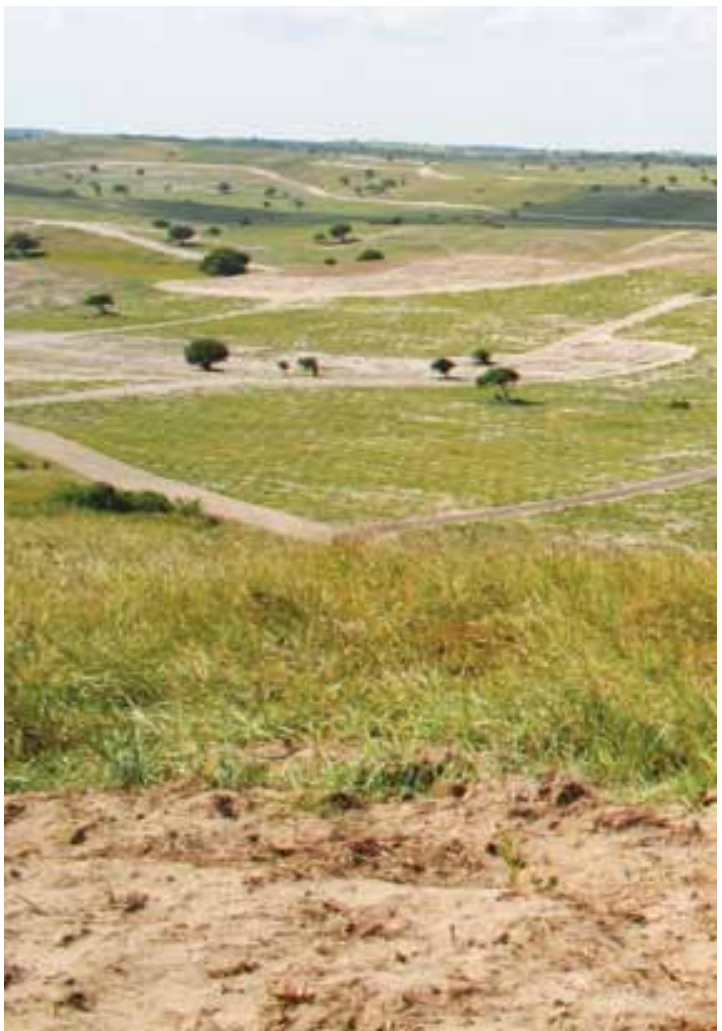

A newly planted, large-scale commercial jatropha farm in Mozambique (Photo by Kevin Setzkorn)

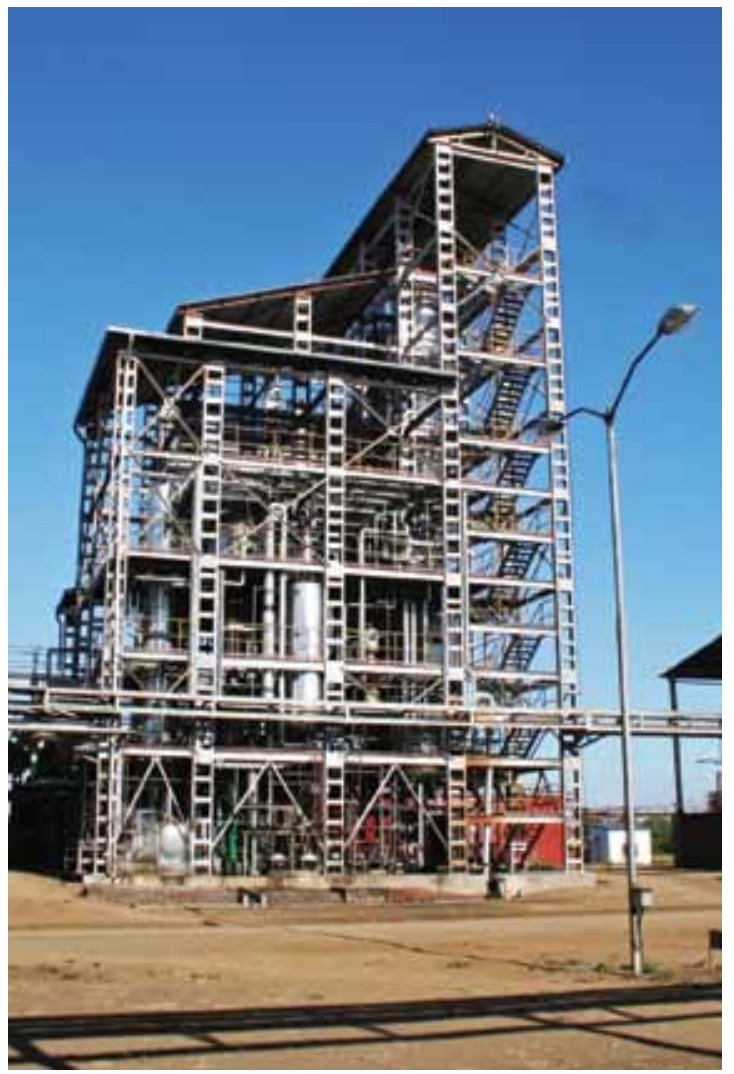

Malawi has been producing ethanol as a fuel blend since 1982 (Photo by Kevin Setzkorn)

\section{Box E. Mozambique expansion into biofuels}

A recently commissioned government study in Mozambique confirmed a potential seven million hectares of land could be available for agricultural expansion. This figure excludes land already allocated for agricultural, conservation or community use. It is anticipated that a few million hectares of this land will be allocated to biofuels. A large number of international investors have already acquired land or are in the process of acquiring land. Large-scale commercial plantations are likely to be the main development models. Already a number of large-scale jatropha plantations are being established, and although some of these plantations are planned to be thousands of hectares in size, typically only a few hundred hectares have been planted. Existing sugar plantations are being rejuvenated and new sugar plantations are planned, including irrigated plantations. Much of the sugar will likely go to biofuels. Mozambique is likely to exceed its local fuel needs from biofuel very rapidly and so most of the biofuel will likely be exported. A few smallgrower projects are currently being undertaken, although it is likely that many companies will look to supporting outgrowers (Haywood et al. 2008). 


\section{Box F. New developments in large-scale biofuel investment}

- ScanFuel director Thor Hesselberg announced in November 2008 that they expect to start commercial operations in Ghana early in 2009, producing 5000 barrels per day of crude oil equivalent by 2015. ScanFuel's operation, based outside Ghana's second largest city of Kumasi, will initially see 10000 hectares planted with the high-oil-yielding jatropha plant with another 10000 hectares reserved for food production. The Ghanaian unit has contracted about 400000 hectares, with up to 60 per cent reserved for biofuel production, 'not less' than 30 percent for food production and the remainder for biodiversity buffer zones (Wendell Roelf, Guardian.co.uk 21 November 2008).

- A South African company, Bio Max, is to invest at least $\mathrm{K} 80$ million in the development of a biofuel processing project from palm oil in Nchelenge, Luapula Province, Zambia, acting Permanent Secretary Clement Siame has disclosed (Times of Zambia 24 November 2008).

- Sweden's Svensk Etanolkemi AB (Sekab) plans to work 100000 hectares of land in the province of Cabo Delgado, northern Mozambique, to supply an ethanol factory in Tanzania, the company's director in Tanzania said in Dar es Salaam. Anders Bergfors said that the company planned to invest US $\$ 300$ million in construction of a factory in Tanzania to produce ethanol from sugarcane, which would be planted both in Mozambique and Tanzania (Macauhub 18 September 2008).

- Britain's Sun Biofuels plans to grow about 5500 hectares of the biofuel plant jatropha in Tanzania in the next 10 years, the firm's local subsidiary said on Thursday (George Obulutsa, Reuters 17 September 2008).

- Daewoo Logistics is taking a 99-year lease on 3.2 million acres of land (in Madagascar), half the size of Belgium, to grow maize and biofuels, building its own roads and other infrastructure to service the new farms that will be created on currently undeveloped open space (Richard Spencer, Telegraph.co.uk 20 November 2008).

The GTZ ProBEC project's media report on biofuels highlights new projects every two months. (Lerner and Schubert 2008)

\section{Competing feedstocks}

Sugarcane, Jatropha curcas and palm oil are the three main feedstocks being promoted and grown in Africa, but other feedstocks are also being considered such as sweet sorghum, cassava and cashew apples (Table 2).

Sugarcane is grown in many African countries, and is a well understood and established crop. Sugarcane produces more biofuel per hectare than any other currently used biofuel crop. Areas in Africa have high sugarcane potential: Zambia has reported production of up to 200 tonnes per hectare $(\mathrm{t} / \mathrm{ha})$, which is three times the international norm of $65 \mathrm{t} / \mathrm{ha}$. Malawi and Ethiopia already produce bioethanol from sugarcane and many other countries are considering the option. In addition there is the potential for cogenerating electricity from sugarcane bagasse (and presumably sweet sorghum) as an added benefit (Naylor et al. 2007).

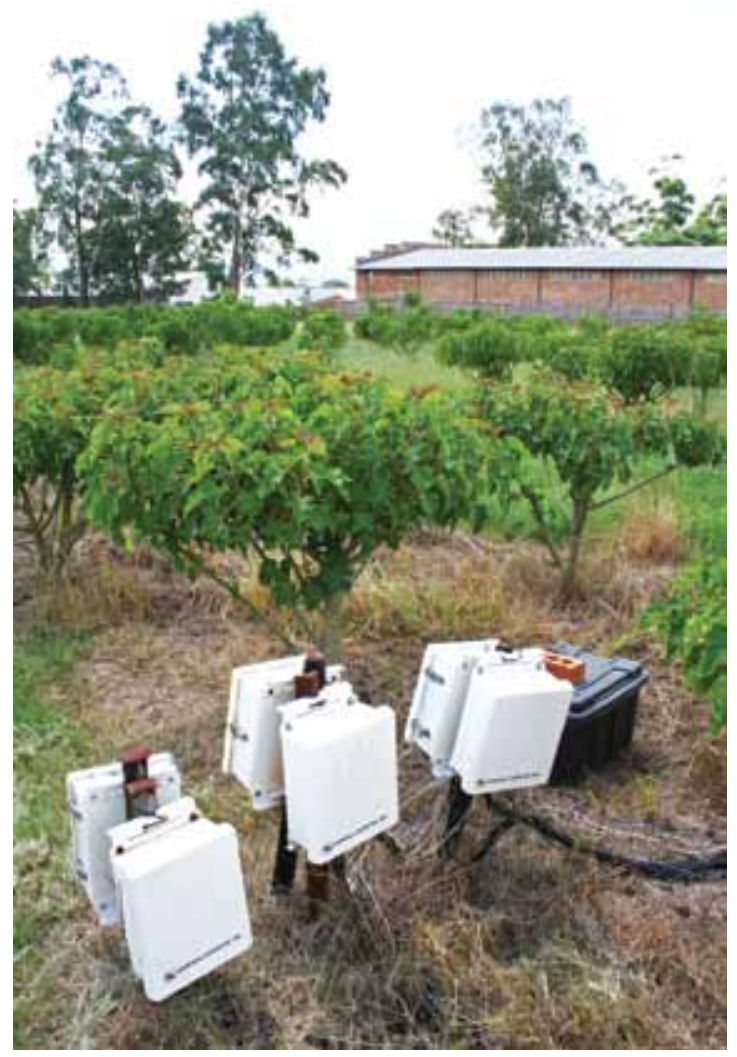

CSIR is conducting detailed studies on the water use and yield of jatropha at its Pietermaritzberg office in South Africa. (Photo by Gareth Borman) 
Table 2. Indicative yields and fuel equivalents from common biofuel crops

\begin{tabular}{|c|c|c|c|c|c|c|c|c|c|c|}
\hline & Sugar & $\begin{array}{c}\text { Sugar } \\
\text { molasses }\end{array}$ & $\begin{array}{c}\text { Sweet } \\
\text { sorghum }\end{array}$ & Maize & Cassava & Jatropha ${ }^{2}$ & Palm oil & Soybean & Canola & Sunflower \\
\hline Litres fuel/t & $60-80$ & 240 & 40 & $366-470$ & 160 & 350 & 230 & 227 & 400 & 400 \\
\hline Tonnes/ha' & $13-105$ & 4.5 & $60^{3}$ & 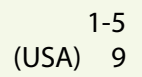 & $\begin{array}{r}3-8 \\
\text { (Thai) } \\
80\end{array}$ & $2-8$ & 20 & 2.67 & 1.4 & $1-2.5$ \\
\hline $\begin{array}{l}\text { Biofuel yield } \\
\text { l/ha }\end{array}$ & $780-8400$ & 1080 & 2400 & $366-3760$ & $480-1280$ & $700-2800$ & 4736 & 446 & 552 & $400-1000$ \\
\hline $\begin{array}{l}\text { Petrol } \\
\text { equivalent/ha }\end{array}$ & 3833 & 756 & 1680 & 2625 & 1304 & & & & & \\
\hline $\begin{array}{l}\text { Diesel } \\
\text { equivalent/ha }\end{array}$ & & & & & & 690 & 4451 & 420 & 550 & 660 \\
\hline $\begin{array}{l}\text { High protein } \\
\text { animal feed as } \\
\text { a byproduct }\end{array}$ & no & no & no & yes & no & no & no & yes & yes & yes \\
\hline
\end{tabular}

Yields vary with location and management. All yields are based on commercial agricultural values. Where possible, the petrol or diesel equivalent is based on data from best practice situations as given by Naylor et al. 2007.

2 These relatively conservative estimates for jatropha are yet to be verified in production systems.

With new varieties and where two crops can be grown per year, yields of sweet sorghum may be much higher.

Jatropha has sparked major interest throughout Africa, with projects currently being implemented in many African countries with suitable climates. South Africa does not support growing jatropha as the country fears that the plant may become a noxious weed. Enthusiastic claims for jatropha's drought hardiness and yields are being tempered by the realisation that jatropha is only likely to yield more than one $\mathrm{t} / \mathrm{ha}$ of oil in areas with more than $800 \mathrm{~mm}$ of rain and where plantations are well managed. Despite the large-scale plantings, and high expectations, many uncertainties still surround the long-term viability of jatropha (Jongschaap et al. 2007; Achten et al. 2008).

African palm oil can produce up to $20 \mathrm{t} / \mathrm{ha}$ of fruit which gives about $4.5 \mathrm{t} / \mathrm{ha}$ of oil. It has been extensively grown for cooking oil, especially in West Africa. Palm oil plants require high rainfall and humidity; this limits plantations to tropical rainforest areas and raises concerns about deforestation (Naylor et al. 2007).

Sweet sorghum, though not currently produced for biofuels, is generating widespread interest as it approaches sugarcane production levels, but in areas of lower rainfall and possibly with less fertilisation. Extensive agronomic trials are being undertaken by the International Crops Research Institute for the Semi-Arid Tropics (ICRISAT), for instance in Zambia and Botswana. A further advantage is that it may be possible to produce both sorghum grain for food and sugar for ethanol concurrently from the same field (Woods 2001).

Maize is the key bioethanol crop in America but although farmers are promoting it as a biofuel crop for South Africa, the Government has discouraged its use because of concerns about food security (Department of Minerals and Energy 2007). Most African maize is a staple food crop and too important as a food to be seriously considered for first-generation biofuel.

\section{Production potential}

With the exception of the extensive Sahelian region in North Africa and the Kalahari/ Namib area in southern Africa, the rest of the continent has sufficient rainfall to support biofuel production (Figure 3a). West Africa has the world's second biggest block of tropical rainforest (see Figure $3 \mathrm{~b}$ ), and there is also a thin belt of rainforest along the east coast. Though rainforest areas would be climatically suited to crops such as sugarcane and palm oil, only already deforested areas should be considered, to avoid a net negative carbon balance that would be unacceptable under international biofuel and biodiversity policy and future climate agreements. Attempts to predict the potential scale of biofuel expansion are hampered by continuing uncertainty over the extent of available deforested and degraded land that is not already currently used for other purposes. 


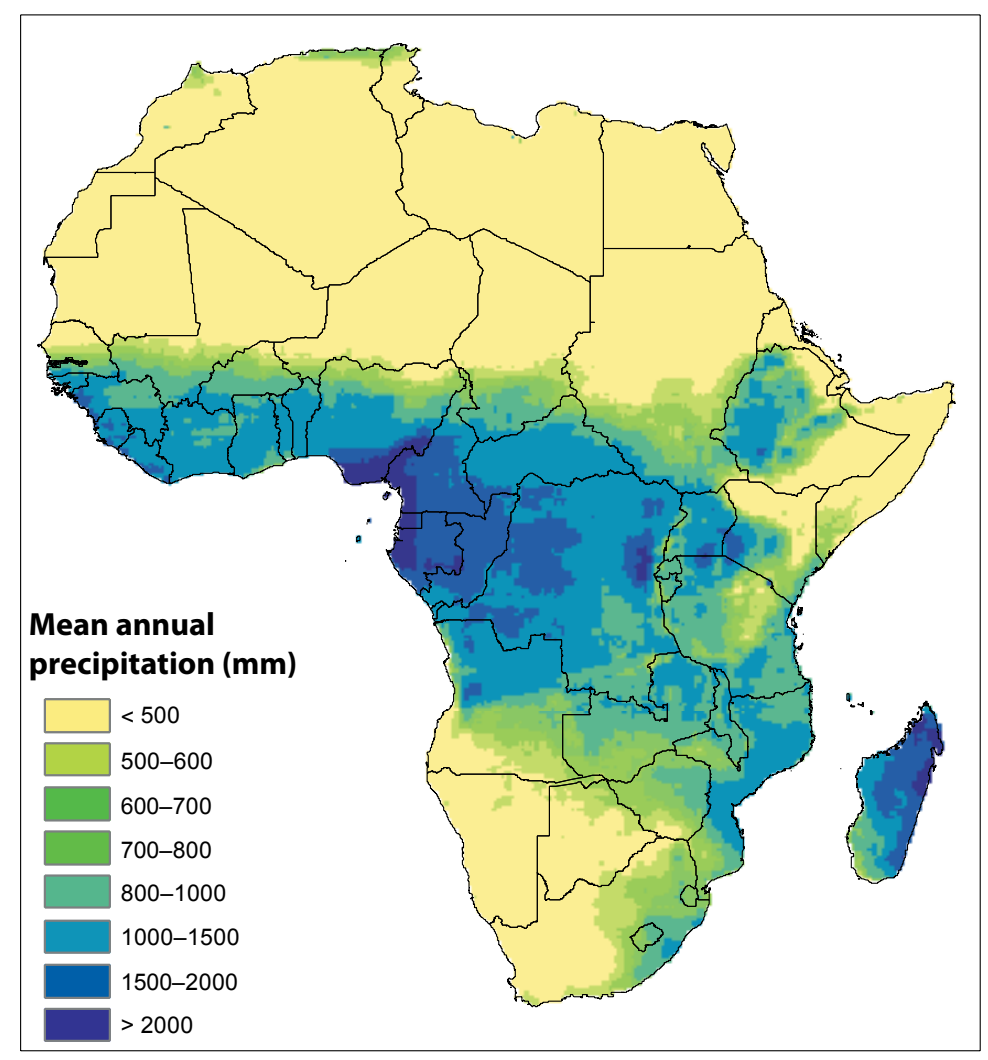

Figure 3a. Mean annual precipitation (GWSP 2008)

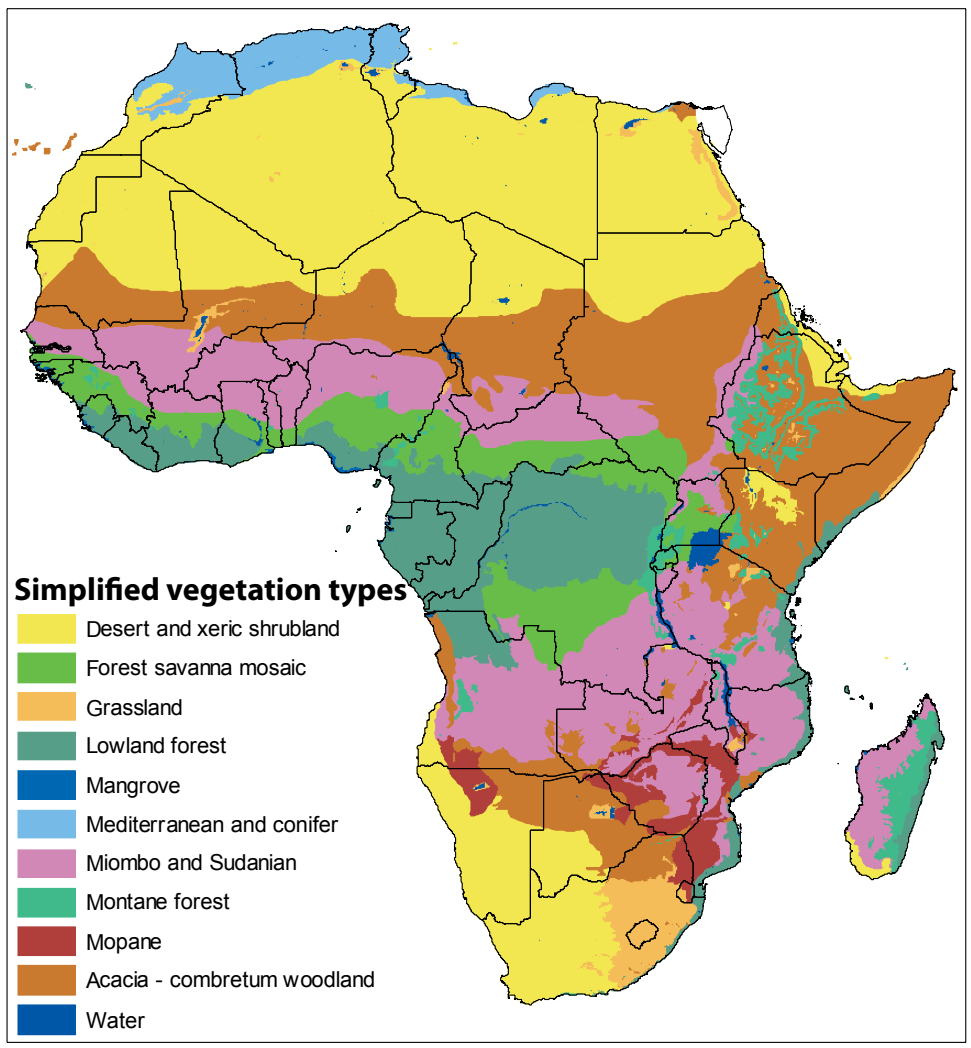

Figure 3b. Simplified vegetation of Africa, based on ecoregions in Olsen et al. 2001 
The extensive deciduous dry forests (commonly referred to as miombo) receive a mean annual precipitation greater than $650 \mathrm{~mm}$ and are likely to be the main area targeted for biofuel expansion. This area is climatically suitable for jatropha, but also potentially for sweet sorghum, cassava and sugarcane. Poor soils have historically limited agricultural expansion in this area, but they can be highly productive with suitable fertilisation (Campbell 1996, Huntley 1982). Yet impacts on carbon stocks and local livelihoods are of equal concern in this environment and must be duly considered.

The arid savanna receives between 400 and $650 \mathrm{~mm}$ rainfall and generally has soils that are generally better than in the miombo. This area receives the lower limit of rainfall suitable for intensive cropping, but may still be suitable for drought-hardy crops such as jatropha and sweet sorghum. Crops such as sugarcane have potential where irrigation is possible, and soils are good.

Exceptionally good soils are associated with the slopes of Africa's ancient volcanic mountains, but these areas are already typically intensively cropped by small-scale farmers for high-value crops. These slopes also have important forests from a biodiversity perspective, and so are likely to induce costs in excess of benefits.

\section{Land needed to meet fuel security}

On a global scale, biofuel production using firstgeneration technologies can only realistically replace a small percentage of fossil fuel. For many African countries, the situation is very different and even first-generation biofuels can provide full fuel self-sufficiency from very limited land areas (see Table 3). Land availability varies widely: countries such as Malawi, Rwanda, Burundi and South Africa have limited land, while countries such as Mozambique, Angola and Zambia have extensive land available. One must use caution in interpreting 'availability,' however, because much of this land is forested and is subject to customary claims. Reliable statistics on land availability are scant and most land is currently being used in some way. Agricultural productivity per hectare in Africa currently falls way below international norms (see Figure 4). It is therefore possible that agricultural intensification could generate

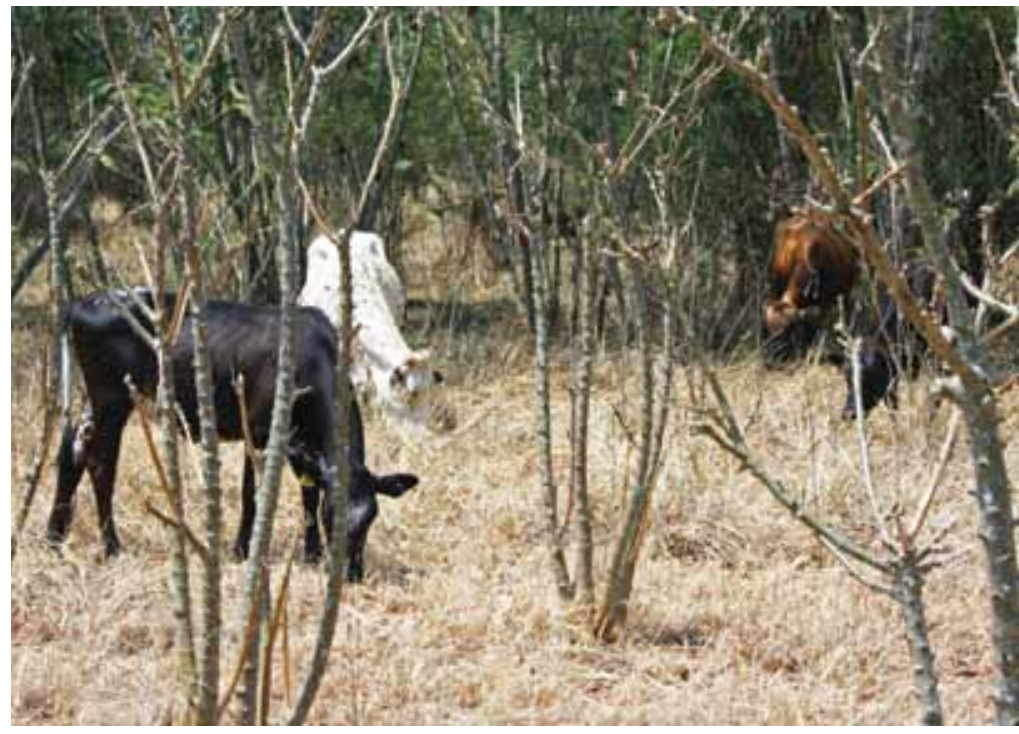

Jatropha responds to a midsummer drought by dropping its leaves in the Makatini flats of South Africa. Although able to withstand dry conditions, seed yields under such conditions are low (Photo by Gareth Borman)

an extensive agricultural surplus that could be diverted into biofuels without affecting local food security. However, caution must be used in ensuring families negatively affected by biofuel expansion are able to benefit in meaningful ways.

Second-generation biofuels would have even greater benefits as they achieve significant 'wellto-wheel' reductions in greenhouse gas (GHG) emissions and require dramatically less land when compared with first-generation biofuels. This is because most biomass, including many organic wastes, can be used as feedstock. Additionally, second-generation biofuels perform better as internal combustion (IC) engine fuels, as they do not have any of the technical problems of degradation and material incompatibility associated with first-generation biofuels (DTI 2006).

\section{Key social considerations}

Globally, the most serious concerns about biofuel expansion focus on the potential impact on global food prices and thereby poverty (Eide 2008; Royal Society 2007). At the global level, the immediate net effect of higher food prices on food security is likely to be negative (FAO 2008). Although sub-Saharan African countries are feeling the pinch from rising food prices, biofuel production at regional and national levels need not diminish regional food security. It has been 
Table 3. Rough estimates on land needed to meet five per cent (two per cent for South Africa) biofuel targets and total fuel needs (based on von Maltitz and Brent 2008)

\begin{tabular}{|c|c|c|c|c|c|c|}
\hline & Botswana & Namibia & Tanzania & S. Africa & Mozambique & Zambia \\
\hline Diesel use in $\mathrm{l} / \mathrm{yr} \times 10^{6}$ & 281 & 445 & 667 & 7987 & 381 & 327 \\
\hline Petrol use in $\mathrm{l} / \mathrm{yr} \times 10^{6}$ & 301 & 325 & 202 & 10289 & 107 & 210 \\
\hline $\begin{array}{l}\text { Percent of total land needed to } \\
\text { meet transport fuel needs }\end{array}$ & 0.9 & 0.9 & 1.2 & 14.6 & 0.8 & 0.8 \\
\hline $\begin{array}{l}\text { Land needed to meet biofuel } \\
\text { targets in ha }\end{array}$ & 26078 & 38917 & 53855 & 307375 & 30631 & 56286 \\
\hline $\begin{array}{l}\text { Estimates of jobs created to } \\
\text { meet biofuel targets }{ }^{2}\end{array}$ & 12251 & 18608 & 26399 & 142919 & 15036 & 27046 \\
\hline $\begin{array}{l}\text { Estimates of jobs created to } \\
\text { meet national fuel usage }\end{array}$ & 245028 & 372160 & 527980 & $\mathrm{n} / \mathrm{a}$ & 300712 & 270458 \\
\hline
\end{tabular}

${ }_{1}^{1}$ All calculations based on sugarcane and jatropha as feedstock, as per Table 2. Values are not linked to specific country or growth conditions and assume suitable land is available.

2 These figures are based on 0.5 jobs per hectare for biodiesel and 0.33 jobs per hectare for sugarcane, as used in Econergy 2008. Most would be low-paying labourer jobs.

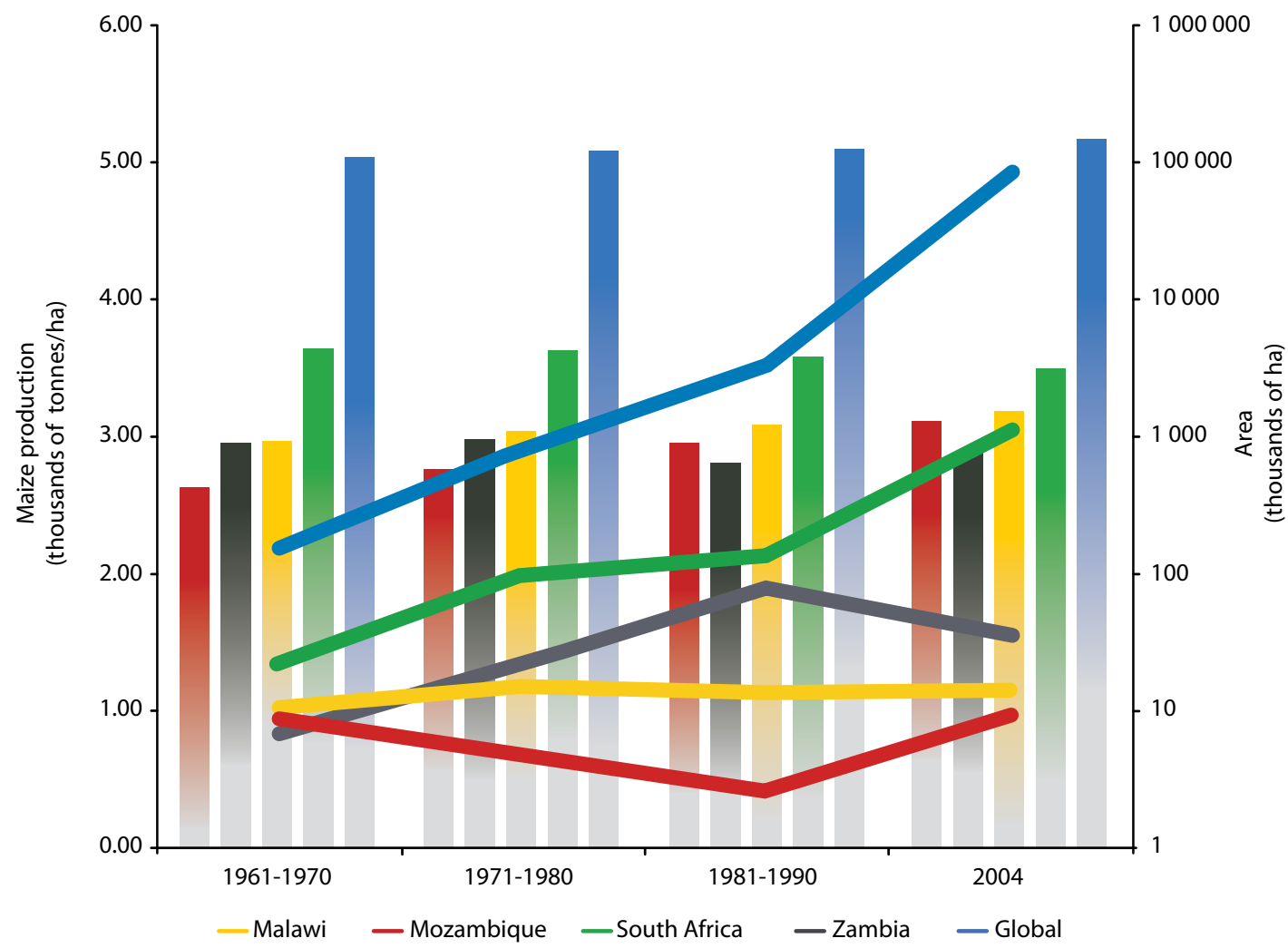

Figure 4. Maize Productivity in African.

Maize productivity in these African countries has not tracked with global trends except in South Africa, which has low production potential compared to global productivity. The bars measure production using the scale on the left. The trend lines measure land use using the log scale on the right. 


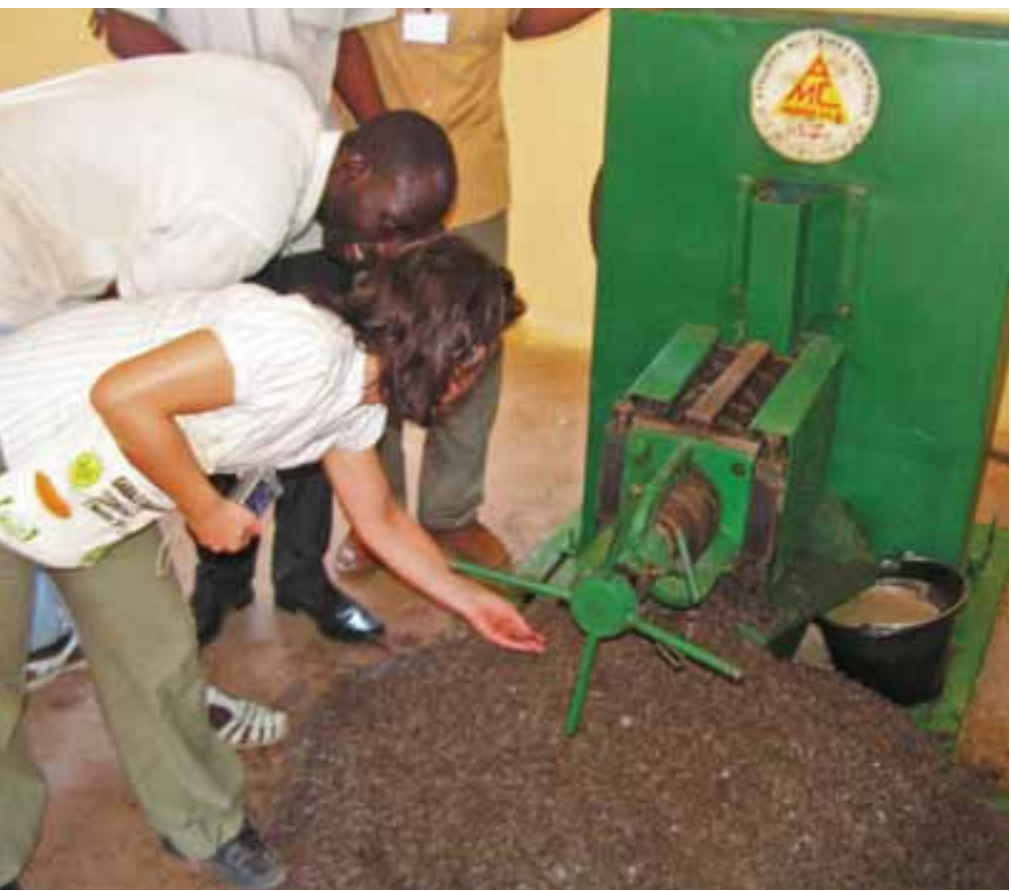

Extracting jatropha oil using a mechanical screw press at Mali Folkecenter, Garalo (Photo by Graham von Maltitz) land's resources. Large-scale biofuel plantations may displace current land users. Where land is governed by a chief or traditional authority, economic benefits to the traditional authority or community as a whole may well overrule existing resource use rights enjoyed by individual members. Caution must be used, however, given increasing evidence that local or customary leaders do not always act in the community's best interest when there are personal benefits to be gained (Brockington 2007; Oyono et al. 2006). Conversion of land for new uses must be based on adequate prior information as well as representative consultation.

Women make up most of Africa's agricultural workforce as they are responsible primarily for growing food crops in rural areas whereas men are responsible for cash-generating crops such as cotton and tobacco. Even though women play the prominent role in agriculture, there is much inequality. From an African perspective this inequality stems from traditional sociocultural roles, and results in women being denied equal access to means of production such as land, credit, appropriate technology and extension services. It is anticipated that in small-scale production, the emerging biofuel industry will have the greatest labour impacts on rural women. Converting land used by women predominantly for food crops to growing energy cash crops instead might cause the partial or total displacement of women's food-growing

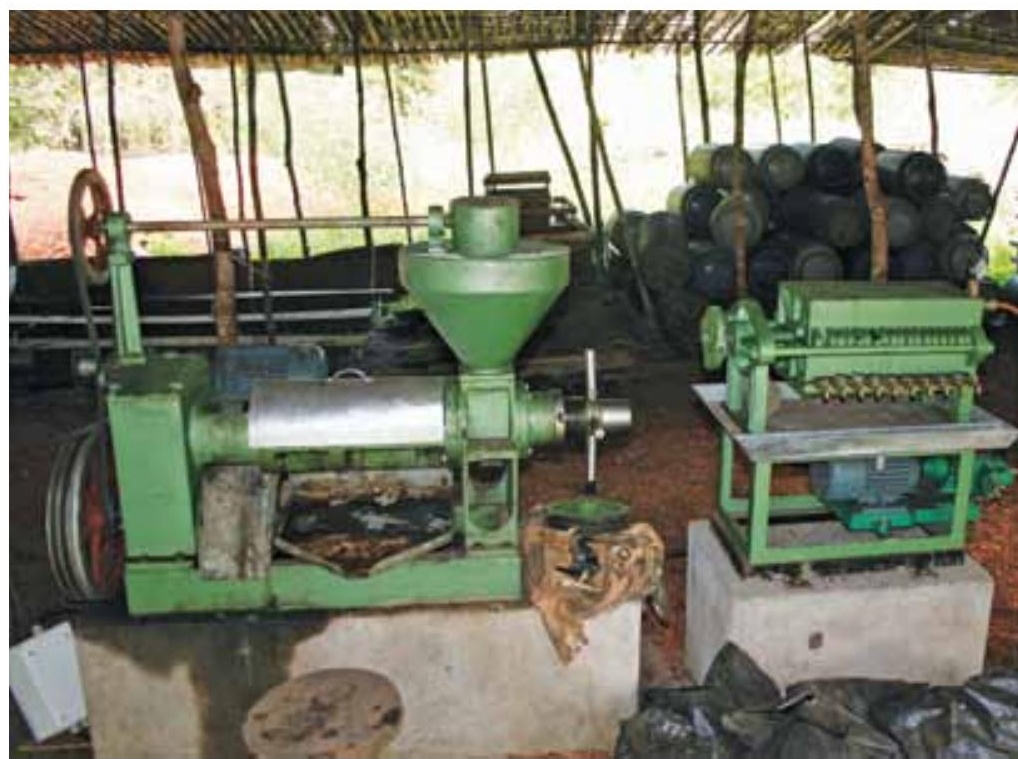

A small screw press for extracting jatropha oil stands idle due to low jatropha yields in a project just outside of Gorongoza Game Reserve, Mozambique (Photo Kevin Setzkorn) 


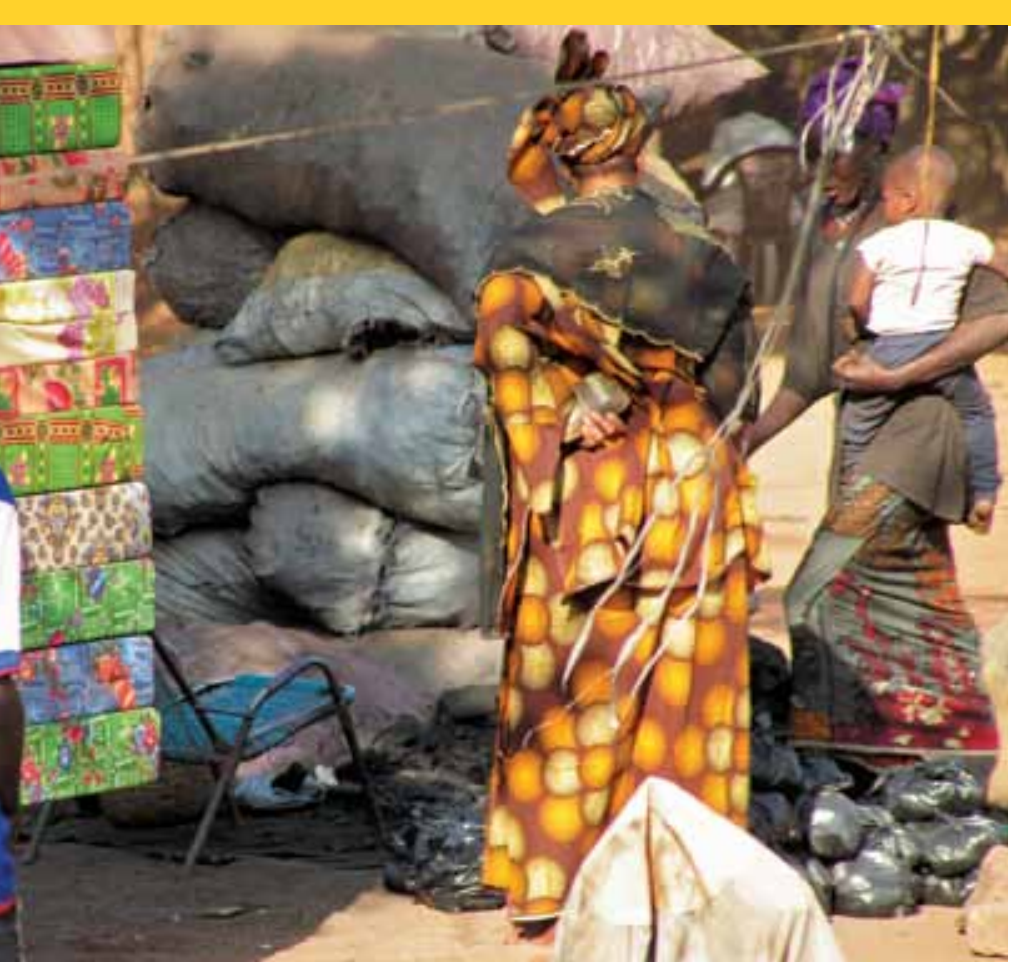

A woman purchases charcoal from a roadside seller in Bamako, Mali (Photo by Graham von Maltitz)

activities towards increasingly marginal land or divert their labour towards activities whose proceeds they have less access to or control over. This would undermine the ability of women to ensure a secure food supply to feed their families (Kajoba 2002; Rossi and Lambrou 2008). In addition, if land traditionally used by women is switched to energy crops, women may then be marginalised in household decision-making about agricultural activities because they control less land.

HIV/AIDS is another serious challenge to agricultural development and, in turn, sustainable biofuel production. HIV/AIDS tends to affect the most productive age group and is characterised by repeated periods of illness. This affects the available agricultural workforce and increases medical expenditure. The extent and severity of HIV/AIDS impacts are most pronounced where periods of sickness or death coincide with peak agricultural seasons. If Africa is to be a global biofuel player, it needs to develop and implement robust policy response options to promote equal opportunities for women and men within the context of HIV/AIDS. This applies particularly to access to food and resources such as assets, capital, technology, agriculture and rural development services, as well as employment opportunities and decisionmaking processes.

\section{Financial viability}

The factors and criteria affecting biofuels' economic/financial viability are national and local in their scope and specifics. Factors include: (a) the cost of biomass materials, which varies depending on land availability, agricultural productivity, labour costs, etc; (b) biofuel production costs, which depend on the plant location, size and technology; (c) fossil fuel costs in individual countries, which depend on fluctuating global petroleum prices and domestic refining characteristics; and, (d) the strategic benefit of substituting imported petroleum with domestic resources. The economics of biofuel production and use will therefore depend upon the specific country and project situation (Thomas and Kwong 2001).

Biofuel production is often a high up-front cost venture, and many programs require government support in the initial start-up phases. Access to affordable financing is a major constraint. Traditional banks are unwilling to provide financing due to market uncertainties and perceived high risks. Investors and financiers have limited data and information on which to base sound judgments and decisions.

Biofuels require a ready market both locally and internationally to guarantee economic viability. Reliable and competitive markets are not yet fully developed in Africa, and the continent has limited access to international biofuel markets.

Market prices for feedstock and fossil fuels largely determine biofuel competitiveness. Given that these prices are highly volatile, investing in biofuel requires closer examination of the longterm market potential and other determinants to minimise the risks. This is particularly important for smallholders, who have limited capacity to weather failed investments. Investors need the security of markets and if the market is to be national, then they may need the assurance of mandatory blending with petroleum products. Economies of scale are also crucial, as is having the knowledge and capacity to select the appropriate feedstock and technology. Lessons can be learned from economic analyses undertaken for selected feedstocks in various countries. This means that the users of renewable energy technologies, and the suppliers of these systems, must all see a financial benefit. This will enable the optimum growth of renewable energy markets; otherwise, 

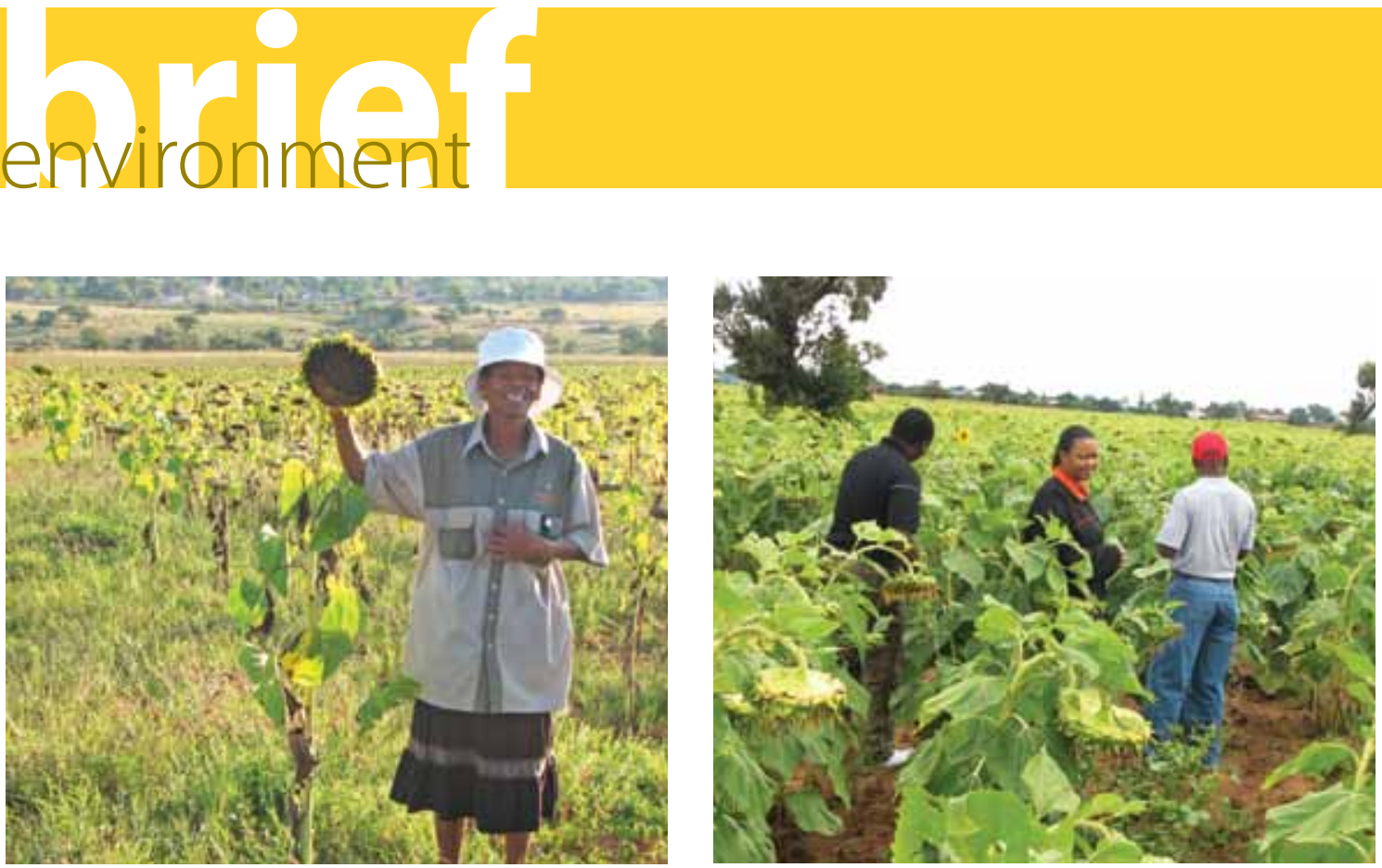

The Mapfura Makhura Incubator assists small-scale farmers in the Groblersdaal area, South Africa, to grow oilseed crops for biodiesel. The growers are planning a cooperative scheme to run a processing plant (Photos by Kevin Setzkorn)

renewable energy will always depend on external finance, grants and short-term policy obligations. For smallholders, evidence suggests that an outgrower approach will generate greater returns to poor people than a more capital-intensive plantation approach due to the greater use of unskilled labour and accrual of land rents to smallholders (Arndt et al. 2008).

\section{Key conclusions}

1) Africa has land available to support biofuel production, but availability varies widely from one region and country to another and competing uses need to be considered. Where land is available, it is important to ascertain that biofuels are the most appropriate land use and will provide greater benefits to the current land users and owners.

2) The land rights and resource rights of indigenous people and disadvantaged groups need to be protected. No land should be allocated without adequate provisions for ensuring existing land users capture benefits from biofuels and without free, prior and informed consent. Such practices have proven extremely difficult to operationalise in practice (Freeman et al. in press).

3) Africa has huge potential for agricultural intensification. A key concern is why this is not occurring with food crops, which almost always are more valuable than fuel crops and should be a first priority.
4) Biofuels in Africa must be for Africa's benefit. Africa must not be used to meet global biofuel demand unless the development has social and economic benefits for Africa. For instance, African countries should be fuel self-sufficient before they export excess feedstock for international use. Policies should also support production models with greater gains for smallholder producers.

5) Biofuel projects must balance local and national benefits. Economic or production efficiency might have to be forfeited to maximise local benefit, for instance through small local processing rather than large central processing.

6) Deforestation and loss of biodiversity remain key concerns. Checks and balances are needed to protect against both social and environmental bad practices.

7) A national cap on land available, a set of land allocation criteria for biofuels and monitoring systems to ensure these standards are respected need to be developed in each country to limit food-fuel conflicts, ensure social sustainability, and keep biodiversity loss within acceptable limits.

8) The implications of second-generation biofuel technologies need to be considered as they may affect the economics of firstgeneration projects in the future. 


\section{References}

Achten, W. M. J., Verchot, L., Franken, Y. J., Mathijs, E., Singh, V. P., Aerts, R. and Muys, B. 2008. Jatropha biodiesel production and use. Biomass and Bioenergy 32 (12): 1063-1084.

African Biodiversity Network (ABN) 2007. Agrofuels in Africa: The impacts on land, food and forests (Case studies from Benin, Tanzania, Uganda and Zambia). African Biodiversity Network, Nairobi, Kenya.

Arndt, C., Benfica, R., Tarp, F., Thurlow, J. and Uaiene, R. 2008. Biofuels, poverty, and growth: A computable general equilibrium analysis of Mozambique. IFPRI Discussion Paper 803.

Brockington, D. 2007. Forests, community conservation, and local government performance: The village forest reserves of Tanzania. Society and Natural Resources 20: 835-848.

Campbell, B. (ed.) 1996. The Miombo in transition: Woodlands and welfare in Africa. CIFOR, Bogor, Indonesia.

Department of Minerals and Energy 2007. Biofuel industrial strategy of the Republic of South Africa. The Republic of South Africa. http:// www.dme.gov.za.

DTI 2006. Second generation transport biofuels: A mission to the Netherlands, Germany and Finland. Global Watch Mission Report, UK.

E4tech 2008. Biofuels review: Advanced technologies overview. Renewable Fuels Agency, Department for Transport, UK. http:// www.dft.gov.uk/rfa/_db/_documents/E4tech_ Advanced_technologies.pdf.

Econergy 2008. Mozambique biofuel assessment. Econergy International Corporation, Washington, D.C.

Eide, A. 2008. The right to food and the impact of liquid biofuels (agrofuels). Food and Agriculture Organisation of the UN, Rome.

Energy Information Association 2005 International Energy Outlook 2005. http://www.eia.doe.gov.

Food and Agriculture Organisation (FAO) 2008 The state of food and agriculture: Biofuels prospects, risks and opportunities. FAO, Rome.

Freeman, L., Lewis, J. and Borreill-Freeman, S., Wiedmer, C., Carter, J., Clot, N. and Tchoumba, $B$. In press. Free, prior and informed consent: Implications for sustainable forest management in the Congo Basin. In German, L., Karsenty, A. and Tiani, A.M. (eds.) Governing
Africa's forests in a globalized world. Earthscan, London.

Gallagher 2008. The Gallagher review of indirect effects of biofuel production. The Renewable Fuels Agency (RFA). http://www.renewablefuelsagency. org/reportsandpublications/ reviewoftheindirecteffectsofbiofuels.cfm.

Global Water Systems Project (GWSP) 2008. Digital water atlas. Map 36: Mean annual precipitation 1950-2000 (version 1.0). http:// atlas.gwsp.org.

Hagan, E. 2007. Biofuels assessment report, ECOWAS subregion, AU/Brazil/UNIDO biofuels seminar in Africa. 30 July-1 August 2007 Addis Ababa, Ethiopia. http://www. unido.org/fileadmin/user_media/Services/ Energy_and_Climate_Change/.../70710_ Biofuels_ECOWAS_Dr._Ben_Hagan.ppt.

Haywood, L., von Maltitz, G., Setzkorn, K., and Ngepah, N. 2008. Biofuel production in South Africa, Mozambique, Malawi and Zambia: A status quo analysis of the social, economic and biophysical elements of the biofuel industry in Southern Africa. CSIR Oxfam draft report for comment. Natural Resources and the Environment, CSIR, Pretoria.

Huntley, B. J. 1982. Southern African savannas. In Huntley, B. J. and Walker, B. H. (eds.) Ecology of tropical savannas. Ecological Studies 42. Springer-Verlag, Berlin.

International Energy Agency (IEA). 2008. Energy technology perspectives: Scenarios and strategies to 2050. OECD/IEA, Paris.

Jongschaap, R. E. E., Corré, W. J., Bindraban, P. S. and Brandenburg, W. A. 2007. Claims and facts on Jatropha curcas L.: Global Jatropha curcas evaluation, breeding and propagation programme. Report 158, Plant Research International B. V., Wageningen, Laren, The Netherlands. http://library.wur.nl/way/ bestanden/clc/1858843.pdf.

Kajoba, G. M. 2002. Women and land in Zambia: A case study of small-scale farmers in Chenene Village, Chibombo District, Central Zambia. Eastern Africa Social Science Research Review 18: 35-62.

Lerner, A. and Schubert, T. 2008. ProBEC biofuels newsletter November-December 2008. GTZ, Program for basic energy and conservation (ProBEC). http://www.probec.org/. 
Maharajh, D. M. and Lalloo, R. 2008. Indigenous algae: Potential factories for biodiesel production. Science real and relevant: 2nd CSIR Biennial Conference, Pretoria, 17-18 November 2008: 7.

Naylor, R. L., Liska, A. J., Burke, M. B., Falcon, W. P., Gaskell, J. C., Rozelle, S. D. and Cassman, K. G. 2007. The ripple effect: Biofuels, food security and the environment, Environment 49(9): 30-43.

Olsen, D. M. et al. 2001. Terrestrial ecoregions of the world: A new map of life on earth. BioScience 51: 933-938.

Oyono, P. R., Ribot, J. C. and Larson, A. M. 2006. Green and black gold in rural Cameroon: Natural resources for local governance, justice and sustainability. Environmental governance in Africa working paper series 22. World Resources Institute, Washington, D. C. and CIFOR, Bogor, Indonesia.

Rossi, A. and Lambrou, Y. 2008. Gender and equity issues in liquid biofuel production. Minimizing the risks to maximize the opportunities. Food and Agricultural Organisation of the UN, Rome.
The Royal Society 2008. Sustainable biofuels: prospects and challenges. Policy document 01/08. The Royal Society, London.

Thomas, V. and Kwong, A. 2001. Ethanol as lead replacement: Phasing out leaded gasoline in Africa. Energy Policy 29: 1113 1143.

Von Maltitz, G. P. and Brent, A. 2008. Assessing the biofuel options for Southern Africa. Science real and relevant: 2nd CSIR Biennial Conference, Pretoria, 17-18 November 2008: 16. http://hdl.handle.net/10204/2579.

Von Maltitz, G. P. and Setzkorn, K. Accepted for publication. Potential impacts of biofuels on deforestation in Southern Africa. Journal of Sustainable Forestry.

Woods, J. 2001. The potential for energy production using sweet sorghum in southern Africa. Energy for Sustainable Development 5(1): 31-38.

The World Bank 2008. The Little Green Data Book. World Bank, Washington, D.C.

For more information, contact:

Markku Kanninen (m.kanninen@cgiar.org)

For general inquiries, contact:

cifor@cgiar.org
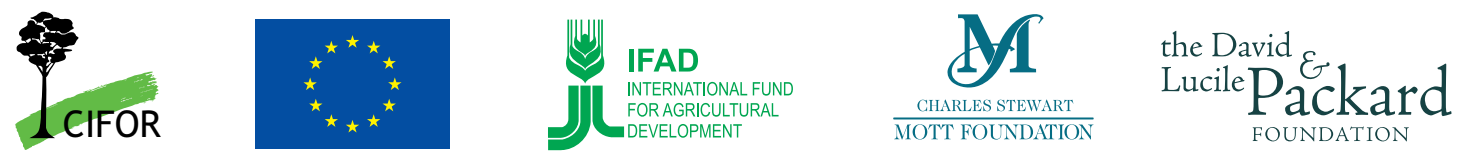

Center for International Forestry Research (CIFOR)

CIFOR advances human wellbeing, environmental conservation and equity by conducting research to inform policies and practices that affect forests in developing countries. CIFOR is one of 15 centres within the Consultative Group on International Agricultural Research (CGIAR). CIFOR's headquarters are in Bogor, Indonesia. It also has offices in Asia, Africa and South America. 